\title{
PEMANFAATAN BANGUNAN BERSEJARAH DALAM MENDUKUNG AKTIVITAS PARIWISATA DI KOTA MEDAN (STUDI KASUS: KAWASAN BANGUNAN BERSEJARAH DI MEDAN POLONIA)
}

\author{
Egi Dhea Trienditha \\ Pendidikan Antropologi Fakultas Ilmu Sosial Universitas Negeri Medan \\ egidtenditha22@yahoo.com
}

\begin{abstract}
Abstrak
Artikel mengkaji peninggalan bangunan tua bersejarah dalam aspek sosial dan budaya. Antropologi pariwisata merupakan ilmu yang mengkaji suatu fenomena dalam berbagai aspek. Diantara yang sangat terlihat adalah mengenai fenomena ataupun siklus dari setiap perubahan yang ada didalam pariwisata tersebut. Di kota Medan sendiri sangat banyak tempat atau bangunan yang berpotensi sebagai kawasan pariwisata yang dapat terus dikembangkan kepopulerannya. Memiliki budaya yang sangat multikultural juga membantu dalam proses pembangunan pariwisata menjadi semakin baik. Nilai jual pariwisata tidak hanya terletak dalam aspek penampilan fisik dari bangunan ataupun pemandangan yang ditawarkan. Namun sumber daya manusia juga harus diperhatikan agar orang yang berwisata merasa aman dan nyaman. Terkhusus di kawasan Medan Polonia sangat banyak bangunan dengan usia yang cukup tua masih tetap eksis, walaupun keberadaannya masih dianggap biasa oleh masyarakat setempat. Berdasarkan pemetaan kawasan Medan Polonia. Pariwisata dengan bentuk bangunan tua bersejarah terdapat cukup banyak. Memiliki potensi cukup baik eksistensinya kurang dikembangkan sesuai dengan kebutuhan pariwisata di kawasan tersebut.
\end{abstract}

Kata Kunci: Sosial Budaya, Bangunan, Bersejarah, Pariwisata

\section{PENDAHULUAN}

Partisipasi masyarakat dalam upaya pelestarian warisan budaya merupakan salah satu prioritas yang harus tercapai dalam setiap kegiatan pemanfaatan bangunan tua bersejarah dalam mendukung kegiatan pariwisata di kota Medan menjadi lebih baik.

Kota Medan merupakan salah satu kota di Indonesia yang memiliki banyak tempat-tempat bersejarah. Salah satu kawasan yang memiliki nilai sejarah dan mempunyai nama dalam dunia pariwisata adalah kawasan Kesawan. Kawasan ini sebenarnya masih membutuhkan tuntunan untuk lebih maju serta berkembang.

Berdasarkan hasil pengamatan, terdapat beberapa bangunan tua bersejarah lain di kota Medan diantaranya adalah rumah Gubernur, rumah Walikota, rumah Pangdam, rumah Kapolda, Rumah Sakit Santa Elisabeth, gereja HKBP Sudirman, gereja GPIB Immanuel, Perguruan Kristen Immanuel, restoran Immanuel, dan Bank Agro.

Upaya pelestarian bangunan tua bersejarah yang dilakukan harus berdampak pada peningkatan kesadaran masyarakat akan pentingnya keberadaan bangunan-benda yang seharusnya dilihat sebagai cagar budaya sehingga masyarakat juga ikut berperan serta, pemerintah juga turut mengayomi dan mengawasi sehingga tidak keluar dari koridor hukum yang berlaku tentang pelestarian dari pemanfaatan kegiatan tersebut. Adapun tujuan daripada pemanfaatan bangunan tua bersejarah ini untuk peningkatan pariwisata di kota Medan dalam berbagai aspek. Dapat dilihat dari segi ekonomi, sosial, budaya, fisik dan sebagainya.

Kegiatan yang dapat dilakukan dalam mengembangkan aktivitas pariwisata tersebut adalah dengan menitikberatkan masyarakat serta golongan mahasiswa sendiri untuk lebih terbuka terhadap permasalahan pariwisata yang selama ini belum terpecahkan. Karena sebenarnya pihak pemerintah sendiri terlalu tertutup dengan objek bangunan tersebut. Selain disatu sisi beberapa bangunan tersebut memiliki fungsi dan pengawasan ketat karena berhubungan langsung dengan kegiatan pemerintahan.

\section{METODE PENELITIAN}

Penelitian berupa mini research ini dilaksanakan dengan tujuan untuk membentuk pemanfaatan bangunan bersejarah dalam mendukung aktivitas pariwisata di kota Medan terkhusus pada kawasan bangunan bersejarah di Medan Polonia.

Objek yang dikaji dalam kegiatan ini sendiri mencakup beberapa hal termasuk dari aspek ekonomi, fisik, sosial, budaya, dan sebagainya. Dalam penelitian ini digunakan pendekatan kualitatif dan bersifat deskriptif.

Berdasarkan analisis tersebut didapatkan informan kunci yang dibutuhkan adalah Dinas Kebudayaan dan Pariwisata Kota Medan, Kepala pemerintahan setempat, Pemerhati cagar budaya kota Medan, Tokoh masyarakat di kawasan cagar budaya, masyarakat yang berada di sekitar kawasan bengunan bersejarah tersebut, dan Akademisi atau pakar. 
Teknik pengumpulan data yang digunakan melalui wawancara mendalam (depth interview), pengamatan di lapangan (observasi), dan analisa data sekunder (Studi Pustaka). Dalam penelitian ini, teknik analisis yang digunakan yaitu teknik analisa deskriptif kualitatif.

\section{HASIL DAN PEMBAHASAN}

Berdasarkan pemetaan kawasan Medan Polonia. Pariwisata dengan bentuk bangunan tua bersejarah terdapat cukup banyak. Memiliki potensi cukup baik eksistensinya kurang dikembangkan sesuai dengan kebutuhan pariwisata di kawasan tersebut. Berikut diantaranya terdapat beberapa bangunan yang berpotensi sebagai kunjungan pariwisata:

\section{Gereja HKBP Sudirman}

Gereja Huria Kristen Batak Protestan (HKBP) terletak di Jl.Sudirman No.17, Anggrung, Medan Polonia, Kota Medan, Sumatera Utara. Gereja ini didirikan tanggal 1 Agustus 1912. Gereja ini merupakan salah satu gereja etnis Batak tertua di kota Medan yang memiliki sejarah yang cukup panjang. Karena itu, gereja ini layak menjadi salah satu heritage dan ikon sejarah bagi kota Medan.

Gereja HKBP ini juga merupakan gereja dengan umat yang jumlahnya paling banyak. Dan telah berkembang baik dari segi bangunan, umat yang beribadah, pimpinan seperti pendeta dan guru jemaatnya. Perlu lebih dikembangkan untuk bidang promosi agar tidak hanya masyarakat Medan dan sekitarnya yang mengetahui tempat ini. Tetapi semua individu dimanapun berada dapat juga mengetahui sejarah dari bangunan gereja tersebut.

\section{Restoran Tamia}

Restoran tamia termasuk bangunan tua yang berada di jalan Dr.Cipto, Polonia Medan. Menurut informan kami, struktur bangunan dari restoran tamia bergaya bangunan Tionghoa dan Melayu. Bahwa juga, restoran Tamia sudah berpindah tempat di Jln. Multatuli sekitaran 20 tahun yang lalu. Tetapi, saat ini bangunan asli Restoran Tamia telah beralih fungsi sebagai sekolah yaitu Sempoerna Academy ABCD di jalan Dr.Cipto, Medan.

Sempoerna Academy bergabung dan bekerja sama dengan Singapore Piaget Academy yang menghadirkan pendidikan berkualitas dan berstandar internasional kepada generasi muda Sumatera Utara. Kenapa hal ini dapat terjadi, padahal bangunan tersebut sangatlah berharga, tetapi pihak pemerintah tidak melihat sisi lain dari aspek sejarah yang ada pada banguna $\mathrm{n}$ tersebut.

\section{Rumah Gubernur}

Rumah Dinas Gubernur Sumatara Utara yang bertempat di jalan sudirman no. 41 Medan polonia. Merupakan salah satu lokasi penelitian selanjutnya, bangunan rumah gubernur ini merupakan salah satu bangunan tua yang sudah berdiri sejak sumatera utara atau kota Medan ada. Rumah gubernur ini merupakan salah satu aset pemerintahan sumatera utara yang di jadikan sebagai tempat peristirahatan gubernur Sumatra Utara. Dari ke 15 gubernur Sumatera Utara hanya gubernur Syamsul Arifin dan Gatot Pudjo Nugroho yang menempati rumah dinas tersebut secara utuh bersama dengan keluarganya selebihnya rumah dinas terssebut digunakan gubernur hanya pada saat ada rapat atau pertemuan penting dan silaturrahmi. Kelebihan dari bangunan ini adalah terdapat taman belakang yang sengaja diletakkan beberapa rusa agar menjadi tontonan masyarakat yang mengunjungi rumah gubernur.

Selain itu bagunan ini dapat di katakan sebagai salah satu bangunan tua dan bersejarah yang dapat menjadi daya tarik bagi masyarakat untuk melihat atau mengunjungi lokasi rumah dinas gubernur. mulai dari kalagan mahasiswa, siswa, dan masyarakat yang datang dengan tujuan yang berbeda-beda. Bangunan dan asitektur yang mengah dapat menjadi alasan utama masyarakat untuk mengunjungi rumah dinas gubernur ini, karena mengingat bangunan ini merupakan salah satu bangunan yang bersejarah dan salah satu aset penting pemerintahan Sumatera Utara maka bangunan ini sangat di rawat dan ketat dengan penjagaan. Bangunan ini sudah berapa kali mengalami renovasi tapi hanya cat nya saja yang di perbarui. Lain lagi bagian atapnya masih ada yang rusak, jendela, asbes dari bangunan bagian belakang ada yang pecah.

\section{Rumah Pangdam}

Selain Rumah Dinas Gubernur, Rumah Dinas Pangdam juga merupakan salah satu bangunan tua dan merupakan aset pemerintahan, rumah pangdam yang berlokasi di jl sudirman, Medan baru. Mengingat karena rumah dinas Pangdam ini merupakan salah satu rumah orang penting di Medan Sumatera Utara maka kapasitas data atau dokumentasi yang didapat dalam penelitian ini terbatas dan bahkan bisa di bilang tidak dapat sama sekali hanya saja sekilas mengamati dari jarak 2 meter. Petugas yang menajaga terlalu agresif, untuk masyarakat ingin mengabadikan moment dibangunan tua itu saja tidak diperbolehkan. Tidak pernah ada artikel ataupun jurnal yang membahas dari beberapa bangunan ini, karena pihak pemerintah sendiri tidak membantu untuk mengembangkan pemanfaatan aktivitas pariwisata di Medan lebih baik.

\section{Rumah Kapolda}

Rumah Kapolda merupakan rumah dinas yang didiami oleh Kapolda sumatera utara. Rumah ini adalah bangunan tua yang memiliki nilai sejarah penting. Mengingat bahwa Kapolda sendiri merupakan bagian terpenting dari negara dan rumah Kapolda sendiri juga bagian dari aset pemerintah yang dijaga hingga saat ini. Rumah dinas ini sendiri hanya ditempati oleh petugas yang berjaga. Bapak Kapolda juga mendiami rumah dinas ini, namun dalam jangka waktu yang tidak lama, mengingat banyak tugas yang harus dikerjakan diluar 
maupun dalam kota. Ketika kelompok kami turun kelapangan disambut oleh Polisi yang berjaga dengan sangat baik. Tetapi hanya saja mereka tidak begitu mengetahui sejarah bangunan rumah Kapolda tersebut.

\section{Rumah Sakit Santa Elisabeth}

Banyak situs di kota Medan yang menjadi saksi sejarah di masa kolonial. Salah satunya adalah rumah sakit ternama ini. Rumah sakit Elisabeth Medan adalah bangunan yang menjadi saksi kegigihan para suster dari Belanda untuk menolong orang-orang sakit di Medan akibat penjajahan Belanda. Rumah sakit ini menjadi saksi juga betapa penjajahan Belanda telah menyebabkan penderitaan bagi masyarakat Medan. Meskipun Belanda dikenal sebagai bangsa yang gemar menjajah, tetapi tidak membuat semua rakyatnya berwatak kolonial. Salah satunya adalah komunitas biara.

Melihat penderitaan yang disebabkan Belanda, membuat seorang uskup dari negeri kincir angina itu mendirikan sebuah komunitas untuk solidaritas kemanusiaan korban perang. Ia adalag Mgr Henricus Van Beek. Van Beek mendirikan sebuah kongregasi Fransiskanes Santa Elisabeth (FSE). Didirikan pada tahun 1880 .

Pada masa penjajahan Jepang rumah sakit ini mengalami pasang surut yang sangat menyedihkan. Sehingga para suster menyerahkan rumah sakit kepada pasukan jepang untuk dijadikan markas tentara. Pada 1945 rumah sakit dikembalikan oleh tentara Inggris kepada para suster. Karena telah diambil oleh Badan Kesehatan Pemerintahan Belanda atau disebut Dienst Van Volks Gezondhied(DVG). DVG menyerahkan rumah sakit kepada suster atas kesepakatan Dr Tengku Mansur dengan Dr Steen sebagai pemimpin DVG. Tanggal 23 Desember 1966 untuk pertama kalinya dibentuk struktur kepemimpinan dan adanya pemisahan yang jelas antara rumah sakit dan biara. Tanggal 25 November 1977, anggaran dasar yayasan diperbaharui, dan tahun 1979 nama yayasan dirubah menjadi Yayasan Santa Elisabeth hingga saat ini.

\section{Rumah Walikota}

Bangunan ini merupakan bangunan bersejarah di kota Medan bekas perumahan villa orang Belanda di kota Medan yang dibangun sekitar tahun 1930an, bangunan ini merupakan ciri bangunan yang bergaya eropa, yang berada di jalan jenderal sudirman nomor 35 Medan polonia kelurahan anggrung. Sebelum menjadi rumah dinas, rumah ini dulunya villa untuk orang Belanda, setelah beberapa tahun terjadi perubahan untuk dijadikan rumah walikota.

Beberapa penambahan yang dilakukan setelah menjadi rumah dinas adalah halaman belakang bangunan dan kondisi rumah walikota ini sangat menarik dan dirawat oleh orang-orang yang bertugas disana. Dan pada bagian-bagian tertentu dan juga pagarnya dihiasi dengan lampu-lampu hias yang memanjang seperti yang terdapat dikawasan lapangan merdeka. Dan untuk penjelasan lebih dalam serta isi bagian dalam bangunan rumah walikota
Medan ini kami kurang mendapatkan lebih detail karena untuk masuk kedalamnya hanya orang tertentu dan yang berkepentingan.

\section{Gereja GPIB Imanuel}

Nilai historis bangunan ini tidak hanya terletak pada jenis bangunannya saja, tetapi juga pada awal pendiriannya. GPIB Immanuel adalah gereja pertama yang berdiri di Kota Medan. Gedung gereja ini terletak di Jalan Diponegoro No 25-27 Medan.

Pesona gereja ini dilambangkan pada cat putih kusam yang mewarnai dinding gedung yang kokoh. Bangunan ini tidak terlampau besar, namun kemegahannya terasa dari setiap detail gedung. Dengan menara yang berbentuk kubah dan jam dinding di masing-masing sisinya menambah kekayaan aksitektur yang bernuansa Belanda kuno. Pintu dengan cat coklat tua menyambut harapan-harapan setiap pengunjung, yang mungkin ingin berdoa atau sekadar berkunjung ke cagar budaya ini. Kubah pada menara gereja ini yang membedakan desainnya dengan gereja-gereja lain di Medan. Kubah tersebut kental sekali dengan peninggalan Belanda yang memang melakukan penyebaran agama Kristen pada masa lalu.

\section{PENUTUP}

Medan merupakan kota yang sangat multikultural, dengan memiliki ragam budaya yang bercorak. Tidak hanya itu, nilai sejarah juga memiliki harga jual yang tinggi sebagai potensi pariwisata di kota Medan. Terlebih untuk kawasan Medan Polonia terdapat banyak bangunan tua yang bersejarah. Bangunan tersebut juga bukan sembarang bangunan biasa, tetapi sejak pertama kali dibangun memiliki fungsi yang sangat baik dalam urusan negara. Walaupun sudah ada beberapa bangunan yang telah beralih fungsi tidak menghilangkan kekhasan dari nilai sejarah yang melekat.

Pariwisata di kawasan Medan Polonia sangat memiliki potensi untuk berkembang jika pemerintah bekerjasama dengan masyarakat untuk membangun Medan yang lebih aman dan tentram. Karena tidak jarang masih banyak ditemukan kasus berbentuk pelecehan terhadap wisatawan baik itu dari luar dan dalam negeri sendiri. Sehingga membuat citra buruk kepada kota Medan yang sebenarnya itu murni kesalahan dari individu yang tidak bertanggung jawab atas perlakuannya. Perlu adanya binaan terhadap orang-orang yang nantinya akan terlibat dalam proses kegiatan pariwisata tersebut. Pemerintah dan masyarakat juga harus lebih terbuka kepada siapapun walaupun unsur kehati-hatian juga tidak boleh dihilangkan sepenuhnya.

\section{DAFTAR PUSTAKA}

Nandi. 2008. Pariwisata dan Pengembangan Sumberdaya Manusia. Jurusan Pendidikan Geografi. Bandung.

Supardan, Dadang. 2009. Pembelajaran Sejarah Berbasis Pendekatan Multikultural Dan Perspektif 
Pemanfaatan Bangunan Bersejarah Dalam Mendukung Aktivitas Pariwisata Di Kota Medan (Studi Kasus: Kawasan Bangunan Bersejarah Di Medan Polonia)

Sejarah Lokal, Nasional, Global, Dalam Integrasi Bangsa (Studi Kuasi Eksperimental Terhadap Siswa Sekolah Menengah Atas Di Kota Bandung). Universitas Pendidikan Indonesia. Bandung.

Sidabutar, Yuanita F.D. 2007. Pemanfaatan Keberadaan Bangunan Bersejarah Dalam Mendukung Aktivitas Pengembangan Wilayah Di Kota Medan (Studi Kasus: Kawasan Kesawan Dan Lapangan Merdeka). Wahana Hijau. Medan.

Pitana, I Gde dan Ketut Surya Diarta. 2009. Pengantar Ilmu Pariwasata. Andi Publishing. Yogyakarta.

Yoeti, Oka A. 1997. Perencanaan dan Pengembangan Pariwisata. Pradnya Paramita. Jakarta. 